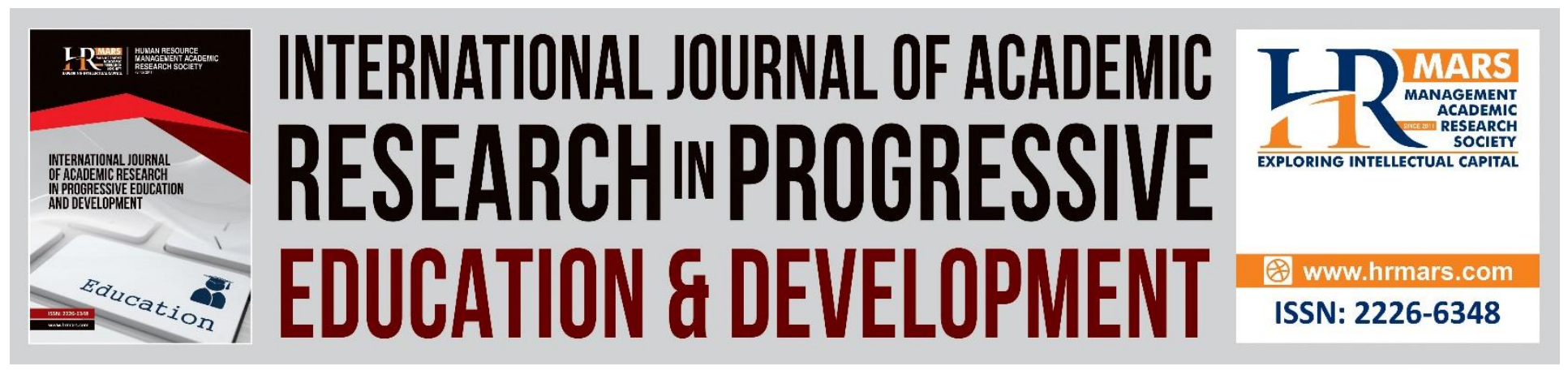

\title{
Identifying the Importance of Types of Music Information among Music Students
}

Norliya Ahmad Kassim, Kasmarini Baharuddin, Nurul Hidayah Ishak, Nor Zaina Zaharah Mohamad Ariff, Siti Zahrah Buyong

To Link this Article: http://dx.doi.org/10.6007/IJARPED/v7-i1/3774

DOI: $10.6007 /$ IJARPED/v7-i1/3774

Received: 12 Dec 2017, Revised: 20 Jan 2018, Accepted: 27 Jan 2018

Published Online: 16 Feb 2018

In-Text Citation: (Kassim, Baharuddin, Ishak, Ariff, \& Buyong, 2018)

To Cite this Article: Kassim, N. A., Baharuddin, K., Ishak, N. H., Ariff, N. Z. Z. M., \& Buyong, S. Z. (2018). Identifying the Importance of Types of Music Information among Music Students. International Journal of Academic Research in Progressive Education and Development, 7(1), 1-11.

Copyright: (C) 2018 The Author(s)

Published by Human Resource Management Academic Research Society (www.hrmars.com)

This article is published under the Creative Commons Attribution (CC BY 4.0) license. Anyone may reproduce, distribute, translate and create derivative works of this article (for both commercial and non-commercial purposes), subject to full attribution to the original publication and authors. The full terms of this license may be seen

at: http://creativecommons.org/licences/by/4.0/legalcode

Vol. 7, No.1, January 2018, Pg. 1 - 11

http://hrmars.com/index.php/pages/detail/IJARPED

JOURNAL HOMEPAGE

Full Terms \& Conditions of access and use can be found at http://hrmars.com/index.php/pages/detail/publication-ethics 


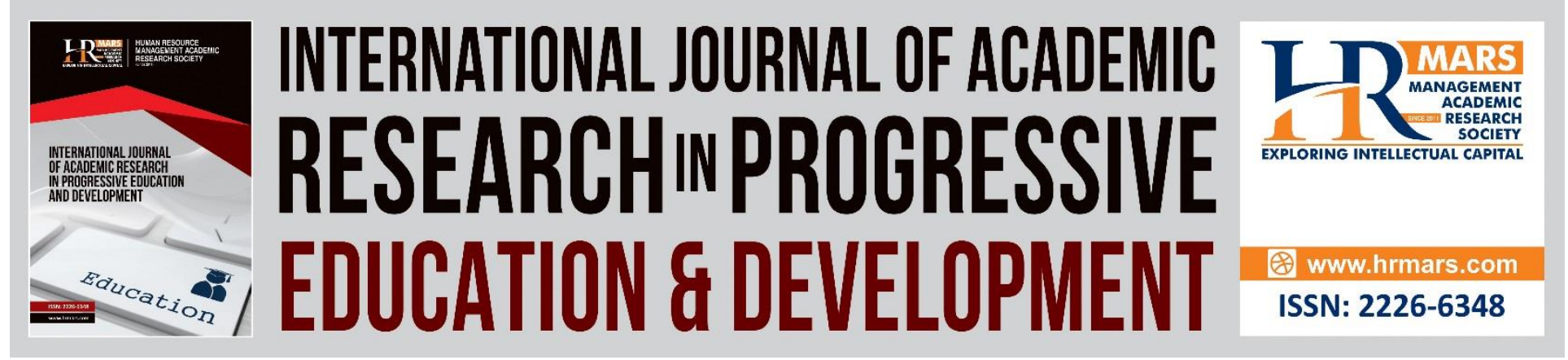

\title{
Identifying the Importance of Types of Music Information among Music Students
}

\author{
Norliya Ahmad Kassim, Kasmarini Baharuddin, Nurul Hidayah \\ Ishak, Nor Zaina Zaharah Mohamad Ariff \\ Faculty of Information Management, Universiti Teknologi MARA (UiTM), Selangor, MALAYSIA \\ Email: norliya@salam.uitm.edu.my
}

\author{
Siti Zahrah Buyong \\ Malaysian Academy of SME and Entrepreneurship Development (MASMED), Universiti Teknologi \\ MARA (UITM), Shah Alam, MALAYSIA \\ Email: zahbuyong8@gmail.com
}

\begin{abstract}
This paper presents part of a study that investigates the level of importance of the various types (kinds) of information needed by music students at the Faculty of Music in one public university in Malaysia. A sample of 150 respondents of music students were taken, of which 130 (86.67\%) of the distributed questionnaire were returned. The findings revealed that two types of music information are perceived by the respondents to be important to their academic matters. They are information related to the notation (mean $=4.14$ ) and music theory (mean $=4.02$ ). The rest are considered as quite important which are aural skill (mean $=3.98)$, music instrument (mean = $3.91)$, music recordings (mean $=3.88)$, rhythms (mean $=3.83)$, music resource (mean $=3.87)$, harmony (chord) (mean $=3.81$ ), arranging (score) (mean $=3.75$ ) and composition (arrangement) (mean $=3.69$ ). There is no evidence of difference regarding the level of importance of music information differences which are gender, age and course among the groups of respondents. The findings will assist the librarians to identify the information required by music students in order to fulfill the students' information needs especially regarding the academic matters towards their academic development.
\end{abstract}

Keywords: Information Needs, Music Information, Music Students, Types of Information

\section{Introduction}

Traditionally, library users come to the library for books, journals, and audiovisual materials. However, for music users, the library is also an important resource for many types of music information. And because there are many kinds of music, various types have been created and published (Lai \& Chan, 2010). In Malaysia, the information needs of music students have largely 


\section{INTERNATIONAL JOURNAL OF ACADEMIC RESEARCH IN PROGRESSIVE EDUCATION AND}

\section{DEVELOPMENT}

Vol. 7, No.1, January 2018, E-ISSN: 2226-6348 @ 2018 HRMARS

been overlooked by information professionals and librarians. These days, as we live in the Information era, the need for information is felt at all levels of society, regardless of an individual's location, social condition or intellectual achievement (Baharuddin, Kassim, Ishak, Ariff, Buyong, 2016).

Previous study found that the information needs are also depending on the discipline of study and level of individual education itself. A study conducted by Hiller (1999) found that users are not consistent and their library use behavior may differ considerably from one person to another depending on their academic discipline, gender, or other factors. It also discovered that the lack of awareness of library resources and services available could be a barrier to information access and lastly the use of resources and services depend on the ability to use information access tools (Bates, 1996).

Besides, there has also been some research on music information seeking behavior in particular. In a survey, Lee and Downie (2004) found that music information seeking is a social process, with $84.6 \%$ of respondents valuing the opinions, reviews, recommendations, or general knowledge of others. They also found a preference for extensive metadata, and propose a framework for organizing music metadata by dividing extra-musical information into content metadata and context metadata. Content metadata is information about the music itself, including bibliographic information such as title, artist, etc. and musical metadata such as melody, tempo, and others. Context metadata includes "relational metadata," such as genre or other similar features, and "associative metadata," such as use in movies or commercials. Over half of the respondents valued relational metadata and expressed a preference to search by "genre" or "similar artists" or "similar music" and, given the fact that high percentages of respondents indicated that music information searches are triggered by "radio," "TV show, movie, or animation," or "advertisement or commercial," the authors assert that associative metadata is needed to improve music information retrieval.

In a preliminary finding of an ethnographic study of music information seeking behavior, Laplante and Downie (2006) reported on the importance of informal channels and music information seeking as a non-goal oriented activity. Their informants preferred information from informal channels such as friends to information from "experts," such as critics or music store employees. However, it was also recognised that friends can be a limited source of information and so it is often still necessary to consult other sources. These sources were typically music-related websites such as allmusic, MySpace, or artist and label websites. In terms of music information searching being a non-goal oriented activity, most of the study's informants could not remember a time searching for music with a specific goal in mind. Music information seeking was reported as an enjoyable activity and typically not motivated by an information need. The authors go on to suggest "discovery"-based music information retrieval systems.

In another study, Narveson (1999) discovered that music user relied most heavily on informal contact with other musicians to learn about playing opportunities and other needs related to playing music. Most of the information needs of the amateur musicians in this study were 
Vol. 7, No.1, January 2018, E-ISSN: 2226-6348 @ 2018 HRMARS

satisfied without the use of the music library. Some of the participants found the Internet was the best source of information regarding music playing.

This paper reports part of a study on information needs of music students in one university that: 1) assess the level of importance of music information needed by music students and 2) compare the difference regarding the level of importance of types of music information needed between gender, age and course of study.

\section{Methods}

A 6-page questionnaire was designed and then distributed among all undergraduate classes from Part 1 to Part 7 of Faculty of Music, Universiti Teknologi MARA (UiTM). Out of the 150 questionnaires distributed, 141 were returned. However, not all the returned questionnaires could be used for data analysis. The final numbers of the questionnaires used for data analysis were 130 (86.67\%). The data obtained from the survey was statistically analyzed using the Statistical Package Social Sciences (SPSS).

\section{Results}

Profile of the Respondents

Table 1 shows that 77 (59.2\%) are male respondents, while 53 (40.8\%) constitutes female respondents. The largest proportion ( 81 or $62.3 \%$ ) of the respondents are those in the $21-23$ age group, followed by those in the 18-20 age group (27 or $20.8 \%$ ) and those in the $24-25$ age group (17 or $13.1 \%$ ). Only 5 (3.8\%) belongs to the 26 and above age group. The course of MU 220 form the largest proportion (63 or $48.5 \%$ ) of the respondents, followed by MU 110 (38 or $29.2 \%$ ) and MU 221 (24 or $18.5 \%$ ) and MU 222 (5 or $3.8 \%$ ). Slightly less than half of the respondents (62 or $47.7 \%$ ) are those in the second year of study. Slightly more than one-third (46 or $35.4 \%$ ) are in the first year of study and followed by $12(9.2 \%)$ are in the third year and $10(7.7 \%)$ are in the fourth and above years of study. The results show that the highest percentages (23 or $17.7 \%$ ) of respondents are specializing in violin, followed by vocal (19 or 14.6\%) and percussion (18 or 13.8 $\%)$. Only one (0.8\%) is specializing French horn. 
INTERNATIONAL JOURNAL OF ACADEMIC RESEARCH IN PROGRESSIVE EDUCATION AND DEVELOPMENT

Vol. 7, No.1, January 2018, E-ISSN: 2226-6348 @ 2018 HRMARS

Table 1: Respondents' Profile

\begin{tabular}{|c|c|c|c|}
\hline \multirow{5}{*}{ Age } & Group & Frequency & Percent \\
\hline & $18-20$ & 27 & $20.8 \%$ \\
\hline & $21-23$ & 81 & $62.3 \%$ \\
\hline & $24-25$ & 17 & $13.1 \%$ \\
\hline & 26 and above & 5 & $3.8 \%$ \\
\hline \multirow[b]{2}{*}{ Gender } & Female & 53 & $40.8 \%$ \\
\hline & Male & 77 & $59.2 \%$ \\
\hline \multirow[b]{2}{*}{ Status } & Married & 1 & $0.8 \%$ \\
\hline & Single & 129 & $99.2 \%$ \\
\hline \multirow{4}{*}{ Course } & MU 220 & 63 & $48.5 \%$ \\
\hline & MU 110 & 38 & $29.2 \%$ \\
\hline & MU 221 & 24 & $18.5 \%$ \\
\hline & MU 222 & 5 & $3.8 \%$ \\
\hline \multirow{4}{*}{$\begin{array}{c}\text { Number of Years } \\
\text { Study }\end{array}$} & 1 & 39 & $30.0 \%$ \\
\hline & 2 & 62 & $47.7 \%$ \\
\hline & 3 & 19 & $14.6 \%$ \\
\hline & 4 And Above & 10 & $7.7 \%$ \\
\hline \multirow{10}{*}{$\begin{array}{l}\text { Specialization of } \\
\text { Musical Instrument }\end{array}$} & Violin & 23 & $17.7 \%$ \\
\hline & Vocal & 19 & $14.6 \%$ \\
\hline & Percussion & 18 & $13.8 \%$ \\
\hline & Guitar & 17 & $13.1 \%$ \\
\hline & Piano & 15 & $11.5 \%$ \\
\hline & Clarinet & 11 & $8.5 \%$ \\
\hline & Flute & 6 & $4.6 \%$ \\
\hline & Cello & 3 & $2.3 \%$ \\
\hline & Oboe & 3 & $2.3 \%$ \\
\hline & French Horn & 1 & $0.8 \%$ \\
\hline
\end{tabular}

Importance of Types (Kinds) of Music Information Needed

What is the level of importance of types (kinds) music information needed by music students?

In this question, the respondents were asked to indicate the level of importance of the various types (kinds) of information they needed using a Likert-scale of $1=$ not important at all; $2=$ not so important; 3 = quite important; 4 = important; and $5=$ very important. The results of the mean scores of perceived importance by types (kinds) of information is listed in descending or order of size (decreasing level of importance).

Following the interpretation of the scoring system (Table 2), two types of music information are perceived by the average respondents to be important to their academic matters. They are 


\section{INTERNATIONAL JOURNAL OF ACADEMIC RESEARCH IN PROGRESSIVE EDUCATION AND}

\section{DEVELOPMENT}

Vol. 7, No.1, January 2018, E-ISSN: 2226-6348 @ 2018 HRMARS

information related to the notation (mean $=4.14$ ) and music theory (mean $=4.02$ ). The rests are considered as quite important, which are: aural skill (mean $=3.98)$, music instrument (mean = $3.91)$, music recordings (mean $=3.88)$, rhythms (mean $=3.83)$, music resource (mean $=3.87)$, harmony (chord) (mean $=3.81$ ), arranging (score) (mean $=3.75$ ) and composition (arrangement) (mean $=3.69$ ). There are other types (kinds) of music information needed that the respondents consider quite important as the information needed, ranging from those related to learning methods (mean $=3.62$ ), music orchestration (mean $=3.58)$, music history (mean $=3.57$ ), video and audio materials (mean $=3.54)$, music counterpoint (mean $=3.52$ ), music bibliography (mean $=3.48$ ), music genre (mean $=3.47$ ) and music background (mean $=3.46)$. The last five are lyrics (3.42), styles (3.40), lyric story (3.34), tempo (3.28) and lastly, private lessons (3.26). It draws to an important conclusion that the respondents are consistent in their perceptions of what constitute important information in their learning process as a music student. The findings showed that the most information needed by respondents are notation and music theory. 
INTERNATIONAL JOURNAL OF ACADEMIC RESEARCH IN PROGRESSIVE EDUCATION AND DEVELOPMENT

Vol. 7, No.1, January 2018, E-ISSN: 2226-6348 @ 2018 HRMARS

Table 2: Level of Importance of Music Information

\begin{tabular}{|c|c|c|}
\hline Information & Mean & Std. Deviation \\
\hline Notation & 4.14 & 1.091 \\
\hline Music Theory & 4.02 & 1.175 \\
\hline Aural Skill & 3.98 & 1.207 \\
\hline Music Instrument & 3.91 & 1.210 \\
\hline Music Recordings & 3.88 & 1.188 \\
\hline Music Resource & 3.87 & 1.190 \\
\hline Rhythms & 3.83 & 1.240 \\
\hline Harmony (Chord) & 3.81 & 1.420 \\
\hline Arranging (Score) & 3.75 & 1.353 \\
\hline $\begin{array}{l}\text { Composition } \\
\text { (Arrangement) }\end{array}$ & 3.69 & 1.402 \\
\hline Learning Methods & 3.62 & 1.405 \\
\hline Music Orchestration & 3.58 & 1.375 \\
\hline Music History & 3.57 & 1.441 \\
\hline Video And Audio Materials & 3.54 & 1.382 \\
\hline Music Counterpoint & 3.52 & 1.388 \\
\hline Music Bibliography & 3.48 & 1.365 \\
\hline Music Genre & 3.47 & 1.442 \\
\hline Music Background & 3.46 & 1.431 \\
\hline Lyrics & 3.42 & 1.456 \\
\hline Styles & 3.40 & 1.367 \\
\hline Lyric Story & 3.34 & 1.417 \\
\hline Tempo & 3.28 & 1.415 \\
\hline Private lesson & 3.26 & 1.315 \\
\hline Overall Mean & 3.54 & 1.334 \\
\hline
\end{tabular}

\section{Results of Reliability and Normality Test \\ Results of Reliability}

Reliability tests were carried out to test the internal consistency of the respective scales for the level of importance of types of music information needed. Jackson (2006) pointed that reliability of instrument allows a similar score each time a researcher used the measuring instrument.

Table 3 shows that the Cronbach's Alpha value on the statement of the level of importance of types (kinds) of music information needed (0.726). It is concluded that, the statement of the level of importance of types (kinds) of music information needed is very reliable as Cronbach's alpha values exceed 0.7 . 
Table 3: Reliability Statistics

\begin{tabular}{|c|c|c|c|}
\hline \multicolumn{4}{|c|}{ Results of Reliability Statistics } \\
\hline \multicolumn{1}{|c|}{ Dimension } & $\begin{array}{c}\text { Cronbach's } \\
\text { Alpha Based on } \\
\text { Cronbach's } \\
\text { Alpha }\end{array}$ & $\begin{array}{c}\text { Standardized } \\
\text { Items }\end{array}$ & $\begin{array}{c}\text { Number of } \\
\text { Items }\end{array}$ \\
\hline $\begin{array}{l}\text { Level Importance of Types of } \\
\text { Music Information Needed }\end{array}$ & 0.726 & 0.722 & 23 \\
\hline
\end{tabular}

\section{Results of Normality Tests}

An evaluation of the normality of data is a requirement for many statistical tests as the normality of data is an underlying assumption in parametric testing. This will help to determine whether data is normal or not normal and use the available techniques.

In this study, the result of the One - Sample Kolmogorov-Smirnov of normality is shown in Table 4. It can be seen that the Z-values (test statistics) for the level of importance of types (kinds) of music information needed is significant at $5 \%$ level $(p=0.200>0.05)$. It is concluded, therefore, that the observation value is normally distributed. Consequently, all statistical tests of significant difference and correlation analyses will use parametric techniques.

Table 4: Tests of Normality

\begin{tabular}{|l|r|r|r|}
\hline \multicolumn{4}{|c|}{ Tests of Normality } \\
\hline \multicolumn{4}{|c|}{ Kolmogorov-Smirnov } \\
\hline Dimension & \multicolumn{1}{|c|}{ Statistic } & \multicolumn{1}{c|}{ Df } & \multicolumn{1}{c|}{ Sig. } \\
\hline $\begin{array}{l}\text { Level of Importance Types of } \\
\text { Information Needed }\end{array}$ & .055 & 130 & $.200^{*}$ \\
\hline
\end{tabular}

Differences of Level of Importance of Types (kinds) of Music Information Needed between Respondents of Different Gender, Age and Course

The study further seeks to determine whether there are demographic differences which are gender, age and course regarding the level of importance of music information needed. Therefore, the gender were grouped into two groups (male and female) while age (e.g.18-20, 2123, 24-26) and course (e.g. MU 110, MU220, MU221) were grouped into three groups. Details of the analysis are presented separately as follows.

\section{Differences between Different Genders}

Table 5 demonstrates the mean difference on the level of importance of types (kinds) of music information needed between gender of respondents using the Independent Samples T-Test. The significant value for the level of importance of types (kinds) of music information needed is not significant at $5 \%$ level $(p=0.303<0.05)$. It is concluded that, there is a difference on the level of importance of types (kinds) of music information needed between genders. 
INTERNATIONAL JOURNAL OF ACADEMIC RESEARCH IN PROGRESSIVE EDUCATION AND

DEVELOPMENT

Vol. 7, No.1, January 2018, E-ISSN: 2226-6348 @ 2018 HRMARS

Table 5: Results of Independent Samples T-Test between Gender

\begin{tabular}{|c|c|c|c|c|c|c|c|c|c|}
\hline \multicolumn{10}{|c|}{ Independent Samples T-Test } \\
\hline & \multicolumn{2}{|c|}{$\begin{array}{c}\text { Levene's Test } \\
\text { for Equality of } \\
\text { Variances }\end{array}$} & \multicolumn{7}{|c|}{ T-Test for Equality of Means } \\
\hline & \multirow[b]{2}{*}{$\mathrm{F}$} & \multirow[b]{2}{*}{ Sig. } & \multirow[b]{2}{*}{$\mathrm{t}$} & \multirow[b]{2}{*}{ df } & \multirow{2}{*}{$\begin{array}{c}\text { Sig. } \\
(2- \\
\text { tailed })\end{array}$} & \multirow{2}{*}{$\begin{array}{c}\text { Mean } \\
\text { Diff }\end{array}$} & \multirow{2}{*}{$\begin{array}{c}\text { Std. } \\
\text { Error } \\
\text { Diff }\end{array}$} & \multicolumn{2}{|c|}{$\begin{array}{l}\text { 95\% Confidence } \\
\text { Interval of the } \\
\text { Difference }\end{array}$} \\
\hline & & & & & & & & Lower & Upper \\
\hline \begin{tabular}{|l} 
Types of \\
Music \\
Information \\
Needed
\end{tabular} & 1.364 & .245 & -1.033 & 128 & .303 & -.09309 & $\begin{array}{r}.0901 \\
0\end{array}$ & -.27138 & .08519 \\
\hline
\end{tabular}

\section{Differences among Different Ages}

Based on the normality test that was conducted, it was discovered that the observation values were normally distributed with respect to the level of importance of types of music information needed. Therefore, the appropriate statistical test of significant difference to use is a parametric test which is One-Way Analysis of Variance (ANOVA).

Table 6 demonstrates the differences in the analysis on the level of importance of types (kinds) of music information needed among respondents' age. The significant value for the level of importance of types (kinds) of music information needed is not significant at $5 \%$ level ( $p=0.708$ $>0.05$ ). It is concluded that, there is no difference regarding the level of importance of types (kinds) of music information needed among the age group.

Table 6: Results of ANOVA Test among Age Group

\begin{tabular}{|l|r|r|r|r|r|}
\hline \multicolumn{7}{|c|}{ ANOVA } \\
\hline Overall Mean for Level of Importance of Types (Kinds) of Music Information Needed \\
\hline & Sum of Squares & \multicolumn{1}{|c|}{ df } & Mean Square & F & Sig. \\
\hline Between Groups & .178 & 2 & .089 & .346 & .708 \\
\hline Within Groups & 32.717 & 127 & .258 & & \\
\hline Total & 32.895 & 129 & & & \\
& & & & & \\
\hline
\end{tabular}

\section{Differences among Different Courses}

Table 7 demonstrates the differences in the analysis on the level of importance of types (kinds) of music information needed among respondents' course of study. The significant value for the level of importance of types (kinds) of music information needed is not significant at $5 \%$ level ( $p$ $=0.780>0.05$ ). It is concluded that, there is no difference regarding the level of importance of types (kinds) of music information needed among respondents' course of study. 
INTERNATIONAL JOURNAL OF ACADEMIC RESEARCH IN PROGRESSIVE EDUCATION AND

DEVELOPMENT

Vol. 7, No.1, January 2018, E-ISSN: 2226-6348 @ 2018 HRMARS

Table 7: Results of ANOVA Test among Courses

\begin{tabular}{|c|c|c|c|c|c|}
\hline \multicolumn{6}{|c|}{ ANOVA } \\
\hline \multicolumn{6}{|c|}{$\begin{array}{l}\text { Overall Mean For Level Of Importance Of Types (Kinds) Of Music Information } \\
\text { Needed }\end{array}$} \\
\hline & Sum of Squares & df & Mean Square & $\mathrm{F}$ & Sig. \\
\hline Between Groups & .128 & 2 & .064 & .249 & .780 \\
\hline Within Groups & 32.767 & 127 & .258 & & \\
\hline Total & 32.895 & 129 & & & \\
\hline
\end{tabular}

\section{Discussions and Conclusion}

As a conclusion, this study has answered the research questions and attained the objective to identify the level of importance of music information needed by music students in completing their academic matters. The findings revealed that information related to notation and music theory are perceived by the respondents to be important to their academic matters. The rest are considered as quite important which are aural skill, music instrument, music recordings, rhythms, music resource, harmony (chord), arranging (score) and composition (arrangement). There is no evidence of difference regarding the level of importance of music information between gender, age and course among the groups of respondents.

This study also has created a good channel for music users to articulate openly and precisely about what they needed. Besides, not only was the survey results useful to the library administrators, but the music faculty was also appreciative of the efforts that the library has put forth. Nevertheless, with the undertaking of this study, it has helped the library understand music users' use behavior and perceived importance of various library materials, thus enabling the library to proactively improve the collection that is tailored to their needs. The findings are useful in providing better library and information services to music students. As a result, it will also enable the librarian to overcome barriers faced by this group of respondents in meeting their information needs.

\section{Acknowledgement}

The authors wish to thank Universiti Teknologi MARA (UITM) and respondents from the Faculty of Music who had participated in this survey.

\section{Corresponding Author}

Kasmarini Baharuddin, Faculty of Information Management, Universiti Teknologi MARA (UiTM), Selangor, MALAYSIA

Email: kas@uitm.edu.my

\section{References}

Baharuddin, K., Kassim, N. A., Ishak, N. H., Ariff, N. Z. Z. M., \& Buyong, S. Z. (2016). Music information needs and methods of getting information among music students in a public 
INTERNATIONAL JOURNAL OF ACADEMIC RESEARCH IN PROGRESSIVE EDUCATION AND

DEVELOPMENT

Vol. 7, No.1, January 2018, E-ISSN: 2226-6348 @ 2018 HRMARS

institution of higher education. International Journal of Academic Research in Business and Social Sciences, 6(10), 44-51.

Bates, M. (1996). Learning about the information seeking of interdisciplinary scholars and students. Library Trends, 45, 159.

Hiller, S. (2010). Assessing user needs, satisfaction, and library performance at University of Washington Libraries. Library Trends, 49, 605-625. Retrieved March 10, 2010 from www.istl.org/02-winter/article1.html.

Jackson, S. L. (2006). Research Methods and Statistics: A Critical Thinking Approach. Beverly, MA: Wadsworth Publishing.

Lai, K. \& Chan, K. (2010). Do you know your music users' needs? A library user survey that helps enhance a user-centered music collection. The Journal of Academic Librarianship, 36(1), 63-69.

Laplante, A., Downie, J. S. (2006). Everyday life music information-seeking behaviour of young adults. Proceedings of the 7th International Conference on Music Information. Retrieval: Retrieved March 1, 2010 from //www.ismir2006.ismir.net/papers/ismir06132_paper.pdf

Lee, J. H., \& Downie, J. S. (2004). Survey of music information needs, uses, and seeking behaviours: Preliminary findings. Retrieved March 21, 2010 from World Wide Web http: //www. ismir2004.ismir.net/proceedings/p081-page-441-paper232.pdf

Narveson, L. (1999). The Information Needs and Seeking Behaviors of Amateur Musicians: A Qualitative Study. Unpublished PhD. Dissertation, University of North Carolina at Chapel Hill. 